\title{
Understanding the Concept of Tubal Blockage in Ayurveda
}

\author{
Trupti Acharya
}

Associate Professor, Dept of Prasuti Tantra Evam Stree Roga, Shobhit University, Kunwar Shekhar Vijendra Medical College \& Research Center, Gangoh, Saharanpur, U.P.

\begin{abstract}
Infertility is the failure to naturally conceive a child even after one or more years of regular unprotected coitus or to carry a pregnancy to full term. The situation gets gloomier as it is a problem often involving multiple factors, the diagnosis and treatment of which puts the family to physical and mental stress in addition to the financial expenses it involves. Tubal blockage is one of the important factors for infertility and it needs to be reviewed from the ancient texts. In this present article attempt has been made to review the tubal blockage in Ayurvedic texts.
\end{abstract}

Keywords: Infertility, Vandhyatva, Ayurveda, Tubal blockage

\section{INTRODUCTION}

Infertility is also defined in specific terms as the failure to conceive after a year of regular intercourse without contraception according to modern science. Causes of infertility include ovulation problems, tubal blockage, age-related factors, uterine problems, previous tubal ligation, endometriosis. 1 According to WHO, positive reproductive health of a woman is a state of complete physical, mental and social wellbeing and not merely absence of disease related to reproductive system and functions. It is observed that $50 \%$ of normal couple achieve conception within three months of regular unprotected intercourse, $75 \%$ in six months and $80-85 \%$ conceive within a year. ${ }^{2}$ Infertility is termed primary if conception has never occurred and secondary if the patient fails to conceive after having achieved a previous conception.
The incidence of infertility in any community varies between 5 and $15 \% .^{3}$

\section{TUBAL BLOCK (INFERTILITY) IN AYURVEDA}

The way to define the disease or the pathogenesis in Ayurveda is entirely different from western medical science, and is based more upon the first vitiation of Doshas, i.e. the pathogenesis of disease from commence. Taking this Ayurvedic view, here an effort has been made to describe the Ayurvedic view regarding tubal blockage in terms of
A) Prakriti, (Doshas; root cause),
B) Adhishthana, (Dushya; seat),
C) Linga (Lakshanas; features)
D) Ayatana. (Ahara Viharadi Nidanas).

\section{A) PRAKRITI (SANNIKRISHTA KARANA OR ROOT CAUSE)}

According to Ayurvedic point of view, the root or ultimate cause of any disease is the vitiation of either one or more of the three Doshas by one or more of their Gunas. ${ }^{4,5,6}$ All the three Doshas can be assumed responsible for Vandhyatva by causing structural or functional abnormalities in Artava Bija Vaha Srotas i.e. fallopian tube. Vitiation of Vata can be considered the most important factor for tubal infertility as it is responsible for Dhatugati ${ }^{7}, \quad$ Cheshta ${ }^{8}$ \& Garbhakriti ${ }^{9}$. Chakrapani has considered Vata the Nimitta Karana of Garbha by saying "Bhetta Karta; Etam Cha Sharir Utapatti Kale" ${ }^{\text {"10 Kapha }}$ can be considered another Dosha responsible for causing tubal block for its 
Avarodhaka and Shophajanaka properties. If Kapha gets vitiated with its Sthira ${ }^{11}$ guna, it can lead to blockage. Acharya Sushruta has also stated that Puya or suppuration ${ }^{12}$ is not possible without Kapha, while Acharya Vagbhata considers Kapha responsible for Shopha or inflammation. These Shopha \& Puya are, of course, the most important causative factors of tubal infertility by producing tubal block. Though Vata \& Kapha seem to be most significant for causing tubal blockage, but the role of Pitta cannot totally be neglected here, as it is said to be responsible for Paka. ${ }^{13}$ Most of the tubal blockages are the consequence of urogenital infection and thus, vitiation of Pitta can be taken here. Hence, tubal infertility is not the manifestation of vitiation of any specific Dosha, rather sometimes interplay of multiple Doshas and sometimes the sequel of vitiation of single Dosha.

\section{B) ADHISHTHANA (DUSHYA: SEAT)}

Garbhashaya is the Adhishthana of this disease entity and the seat of Doshic vitiation too. On the basis of various references given in classics, Adhishthana can be defined in various terms but the ultimate one is Garbhashaya (uterus) only. Acharya Sushruta has considered four factors essential for the conception. These factors are; Ritu (proper time i.e. ovulatory period), Kshetra (genital organs especially uterus), Ambu (nourishing substances) and Bija (gametes). Acharya Ghanekar has also considered Garbhashaya or Garbhashaiya as Kshetra for Garbhadhana, though he has also taken it as Stree in a broader sense. ${ }^{15}$ Fallopian tubes are the part of uterus itself, thus, is definitely the component of the Kshetra here. Hence, the Kshetra stated by Acharya Sushruta can be considered as the Adhishthana of vitiation of Doshas.. While describing the factors, which are essential to be in proper and healthy state for conception and partum, Acharya Charaka has clearly mentioned term Ashaya other than the Asrik or $B i j a^{16}$. It clarifies the need for normal function of both the ovulatory and uterine factors for conception. So, if the Ashaya is not Sampad, it can mean the abnormality either in uterus or in tube in the form of block. When Doshas are localized in fallopian tube, it leads to tubal block.

\section{C) LINGA (LAKSHANA: CLINICAL FEATURES)}

Acharya Charaka ${ }^{17}$ has not mentioned Vandhyatva in such a way but if we go through the literature the Sapraja Vandhyatva can be considered as a consequence of tubal infertility, because the post - partum infection of reproductive organs can cause tubal blockage.

Acharya Harita ${ }^{18}$ has explained 6

types of Vandhyatva out of them Kakavandhya and Anapatya are the secondary and primary types of infertility, and tubal blockage can lie behind these disorders along with several other possible causes. Dhatukshaya can be considered either as tuberculosis affecting reproductive organs or may indicate a condition of emaciation along with reduced immunity making her susceptible for recurrent infections. Both the above condition may finally lead to occlusion of tubal lumen causing Vandhyatva. Garbhasamkocha seems to be nearer to tubal infertility, because coitus before the age of menarche is the reason of infertility here. It denotes that a girl, who was normal previously, becomes infertile due to coitus at an improper age. Coitus is a responsible factor for altering the vaginal $\mathrm{pH}$, which makes it prone to bacterial growth and infection. This infection, if ascends towards the upper genital tract is known as Pelvic Inflammatory Disease (PID), and if not treated properly, may cause tubal blockage

\section{Tubal blockage in Yoni Vyapadas}

Tubal blockage is a common complication of Pelvic inflammatory disease i.e. infection of upper genital tract. Acharya Charaka $^{19}$ and Vagbhata ${ }^{20}$ have considered infertility as a complication of all the Yonivyapadas. Thus, tubal blockage can be taken as complication of those 
Yonivyapadas, which are compared with PID on the basis of their symptomatology.

1. Paittika or Pittala- is compared with the infection of reproductive organs. ${ }^{21,22,23,24}$

2. Tridoshaja or Sannipatiki This Yonivyapad is considered as acute infective disorder of reproductive system either developed due to infection of reproductive system itself or as a consequence of disorder of another system, ${ }^{25,26,27,28}$ for its characters like Burning sensation with pain, yellowish and white unctuous vaginal discharge As this condition is a clear cut description of mixed type of severe genital tract infection, it may definitely lead to infertility as a consequence by producing tubal block as a complication.

3. Aticharana Here Acharya Charaka \& Vagbhata have given features of Shopha, Supti \& Ruja due to Ativyavaya, while Acharya Sushruta has clearly indicated the infertility by saying Yasya Bijam $\mathrm{Na}$ Vindati. The disease Aticharana appears to be analogous to vaginal inflammation caused by excessive coitus associated with infertility. ${ }^{29,30,31,32}$ It can be considered a condition very nearer to tubal infertility, as any infection, if leads to infertility, is due to tubal blockage.

4. Paripluta ${ }^{33,34,35}$ It is again a condition very similar to the preliminary stage of tubal blockage, because all the features given are suggestive of its similarity with Pelvic Inflammatory Disease.

5. Upapluta ${ }^{\mathbf{3 6}, 37}$ This Yonivyapad again refers to condition of genital tract infection with Pandu, Satoda, Shweta \& Pichhila Srava with dominance of Kapha \& Vata leading to Shopha and Vedana. In this Vatakaphajanya Avarodha as well as infection can cause the tubal blockage.

6. Vipluta ${ }^{38}$ Acharya Sushruta has considered Vipluta a disorder characterized by Nitya vedana (continuous pain), and indicated it as a Vatika disorder. If infertility is assumed as a complication of this condition left untreated, there can be several pathologies regarding different type of ovulatory, uterine and other factors. Tubal blockage undoubtedly can be one of those pathologies by causing Sankocha (stenosis) of tubal lumen because of increased Rukshatva of aggravated Vata.

\section{D) NIDANAS (ETIOLOGICAL FACTORS)}

Table no 1: Tubal blockage caused by Nija Hetu (internal factors)

\begin{tabular}{|c|c|c|c|c|}
\hline Doshas & Nidanarthakar roga & Nidanas & Vikriti & Nimitta \\
\hline \multirow[t]{2}{*}{ Vata } & Aticharana & Ativyavaya & Shopha & Agantuja \\
\hline & Vipluta & & Sankocha & Nija \\
\hline \multirow[t]{3}{*}{ Pitta } & Pittala Yonivyapada & Pittaja Ahara & Paka & Nija \\
\hline & Pittaja Artavadushti & $\begin{array}{ll}\text { Pittaja } & \text { Ahara } \\
\text { Vihara } & \\
\end{array}$ & Paka & Nija \\
\hline & Pittaja Asrigdara & Pittaja Ahara & Paka & Nija \\
\hline \multirow[t]{2}{*}{ Kapha } & $\begin{array}{l}\text { Kaphaja Artava } \\
\text { dushti }\end{array}$ & $\begin{array}{l}\text { Kaphaja } \\
\text { Vihara }\end{array}$ & Shopha & Nija \\
\hline & Kaphaja Asrigdara & Kaphaja Ahara & Shopha & Nija \\
\hline Vata Pitta & Paripluta & $\begin{array}{ll}\text { Vega } & \text { Dharana(Kshavathu } \\
\text { Udgara) } & \end{array}$ & ShophaPaka - & Nija \\
\hline
\end{tabular}

Agantuja Rogas (External factors) which can cause tubal blockage

Sapraja: This condition seems to be Agantuja Nimittaja Vyadhi, as secondary infertility is generally the consequence of trauma or post - partum infection and that may be the reason why Acharya has not described Doshas \& Nidanas for this condition.
Kakavandhya: Secondary infertility told by Acharya Harita can be explained in similar manner.

Balakshaya: As per the abovementioned explanation, this condition seems to be genital tuberculosis caused by mycobacterium. And it also can be understood as Agantuja Nimittaja Vyadhi leading to tubal blockage. 
Garbhasankocha caused by coitus in an immature girl told by Acharya Harita is again a clear description of infertility caused by tubal \& cervical stenosis, thus, an Agantuja Nimittaja Vyadhi.

Upadamsha: It denotes venereal diseases caused by improper coitus. It is Agantuja Vyadhi which may definitely lead to tubal infertility.

Parisruta: Nidanas mentioned for all the Jataharinis mainly speak about to contagious and infectious etiological factors. Thus, Parisruta told by Acharya Kashyapa is definitely an Agantuja Vyadhi, which is generated by influence of Daiva Karanas.

\section{CONCLUSION}

Infertility has increased tremendously in the past decade and this is due to the result of a combination of social, environmental, psychological, and nutritional factors. The management of infertility due to tubal factor in modern includes Tubal microsurgery, Laparoscopic tubal adhesiolysis, fimbrioplasty and tubal surgery, in vitro fertilization, Tubal cannulation etc. But these modalities have their own demerits. The chief among the adverse effects are anaesthetic complications, post operative wound infection, chest infection, embolism, failure of surgery and high incidence of ectopic pregnancy in post treatment cases. The treatment is very expensive also. Better understanding of tubal blockage as per Ayurvedic texts is the need of the time so that researchers can develop safer, more cost effective and complete cure of this sensitive problem.

Acknowledgement: None

Conflict of Interest: None

Source of Funding: None

\section{REFERENCES}

1. Daar A, Merali Z. "Infertility and social suffering: the case of ART in developing countries", In: Vayena E, Rowe P, Griffin $\mathrm{D}$, editors. Report of a meeting on "Medical, Ethical, and Social Aspects of Assisted Reproduction; 2001 17-21 Sept; Geneva, Switzerland: WHO, 2002; 16- 21.

2. Howkins and Bourne. Shaw's Textbook of Gynaecology, 14th ed., Noida; Reed Elsevier India Private Limited, 2009; 180.

3. Howkins and Bourne. Shaw's Textbook of Gynaecology, 14th ed., Noida; Reed Elsevier India Private Limited, 2009; 180.

4. Chakrapani commentary on Charaka samhita, Chaukhamba samskrit Samsthana, Varanasi, 1984, Ch. Su. 20/9

5. Ayurveda-Tattva Samdipika Vyakhya, Sushruta Samhita, 24/9

6. Pt. Hemraja Sharma, Vidyotini Hindi commentary, Kashyapa Samhita, Chaukhamba Sanskrit Sansthan, Varanasi (2009),Kash. Su. 27/29

7. Pt. K. N. Shastry \& G. N. Chaturvedi, Vidyotini Vyakhya, Charaka Samhita, Chaukhamba Bharati Academy, 2005Ch. Su. $18 / 49$

8. Ibid, Vidyotini Vyakhya, Ch. Su. $17 / 116$

9. Ibid, Vidtotini Vyakhya, Ch. Su. 17/7/2

10. Chakrapani commentary on Charaka samhita, Chaukhamba samskrit Samsthana, Varanasi, 1984 Ch. Su. 12/8

11. Pt. K. N. Shastry \& G. N. Chaturvedi, Vidyotini Vyakhya, Charaka Samhita, Chaukhamba Bharati Academy, 2005Ch. Su. $1 / 61$

12. Ambikadutta Shastry, 'Ayurveda Tattva Sandipika' Vyakhya, Chaukhamba SanskritSansthana, Varanasi Sushruta Samhita,Su.Su-17/12

13. i.b.i.d

14. Ibid Su. Shar $2 / 33$

15. Dr. D. B. Ghanekar, Ayurveda Rahasya Dipika Vyakhya Su. Shar., Meharchand Lakshman Das Publication, 13th edition, 1998, Su.Shar $2 / 34$

16. Pt. K. N. Shastry \& G. N. Chaturvedi, Vidyotini Vyakhya, Charaka Samhita, Chaukhamba Bharati Academy, 2005Ch. Shar $2 / 6$

17. Pt. K. N. Shastry \& G. N. Chaturvedi, Vidyotini Vyakhya, Charaka Samhita, Chaukhamba Bharati Academy, 2005Ch. Shar 2/7 
18. P. Haridas Tripathi, 'Hari' Vyakhya, Harita Samhita, Chaukhamba Krishnadas Academy, Varanasi 2005 Ha.S.Tritiya Sthana 48/5,6

19. Pt. K. N. Shastry \& G. N. Chaturvedi, Vidyotini Vyakhya, Charaka Samhita, Chaukhamba Bharati Academy, 2005Ch . Chi 30/37,38

20. Kaviraj Atrideva Gupta, Vidyoyini Tika, Ashtamg Hridaya, Chaukhamba Prakashan, Varanasi (2007) A. H. U. 33/52

21. Pt. K. N. Shastry \& G. N. Chaturvedi, Vidyotini Vyakhya, Charaka Samhita, Chaukhamba Bharati Academy, 2005Ch . Chi 30/11,12

22. Ambikadutta Shastry, 'Ayurveda Tattva Sandipika' Vyakhya, Chaukhamba SanskritSansthana, Varanasi Sushruta Samhita,Su.U-38/14

23. Kaviraj Atrideva Gupta, Vidyoyini Tika, Ashtamg Hridaya, Chaukhamba Prakashan, Varanasi (2007) A. H. U. 33/42,43

24. Prof. P. V. Tewari, Ayurvediya PrasutiTantra \& Stri-Roga, Vol. 1, 2nd edition, ChaukhambaOrientalia, Varansi, pg. 17

25. Pt. K. N. Shastry \& G. N. Chaturvedi, Vidyotini Vyakhya, Charaka Samhita, Chaukhamba Bharati Academy, 2005Ch . Chi 30/14

26. Ambikadutta Shastry, 'Ayurveda Tattva Sandipika' Vyakhya, Chaukhamba SanskritSansthana, Varanasi Sushruta Samhita,Su.U-38/14

27. Kaviraj Atrideva Gupta, Vidyoyini Tika, Ashtamg Hridaya, Chaukhamba Prakashan, Varanasi (2007) A. H. U. 38/52

28. Prof. P. V. Tewari, Ayurvediya PrasutiTantra \& Stri-Roga, Vol. 1, 2nd edition, ChaukhambaOrientalia, Varansi, pg. 20

29. Pt. K. N. Shastry \& G. N. Chaturvedi, Vidyotini Vyakhya, Charaka Samhita,
Chaukhamba Bharati Academy, 2005Ch . Chi 30/19

30. Ambikadutta Shastry, 'Ayurveda Tattva Sandipika' Vyakhya, Chaukhamba SanskritSansthana, Varanasi Sushruta Samhita,Su.U-38/16,17

31. Kaviraj Atrideva Gupta, Vidyoyini Tika, Ashtamg Hridaya, Chaukhamba Prakashan, Varanasi (2007) A. H. U. 33/31

32. Prof. P. V. Tewari, Ayurvediya PrasutiTantra \& Stri-Roga, Vol. 1, 2nd edition, ChaukhambaOrientalia, Varansi, pg. 28

33. Pt. K. N. Shastry \& G. N. Chaturvedi, Vidyotini Vyakhya, Charaka Samhita, Chaukhamba Bharati Academy, 2005Ch . Chi 30/23,24

34. Ambikadutta Shastry, 'Ayurveda Tattva Sandipika' Vyakhya, Chaukhamba Sanskrit Sansthana, Varanasi Sushruta Samhita, Su.U-38/10,11

35. Kaviraj Atrideva Gupta, Vidyoyini Tika, Ashtamg Hridaya, Chaukhamba Prakashan, Varanasi (2007) A. H. U. 33/46,47,48

36. Pt. K. N. Shastry \& G. N. Chaturvedi, Vidyotini Vyakhya, Charaka Samhita, Chaukhamba Bharati Academy, 2005Ch . Chi 30/21,22

37. Kaviraj Atrideva Gupta, Vidyoyini Tika, Ashtamg Hridaya, Chaukhamba Prakashan, Varanasi (2007) A. H. U. 33/48,49

38. Ambikadutta Shastry, 'Ayurveda Tattva Sandipika' Vyakhya, Chaukhamba SanskritSansthana, Varanasi Sushruta Samhita,Su.U-38/10,11

How to cite this article: Acharya $\mathrm{T}$. Understanding the concept of tubal blockage in ayurveda. International Journal of Research and Review. 2021; 8(8): 272-276. DOI: https://doi.org/10.52403/ijrr.20210837 